\title{
НАНОФАРМАКОЛОГІЯ: ВИКЛАДАННЯ НА ДОДИПЛОМНОМУ ЕТАПІ СТУДЕНТАМ МЕДИЧНИХ ФАКУЛЬТЕТІВ
}

\section{I. С. Чекман}

\author{
Національниймедичний університет імені О. О. Богомольия
NANOPHARMACOLOGY: TEACHING FOR STUDENTS OF MEDICAL FACULTY ON PRE-GRADUATE STAGE

\author{
I.S. Chekman
}

\author{
National Medical University by O. O. Bohomolets
}

\begin{abstract}
Нанофармакологія - новий напрям лікознавства, що вивчає властивості нанопрепаратів, особливості їх взаємодії 3 організмом [2]. Викладання студентам медичного факультету нанофармакології на додипломному етапі мас важливе навчально-методичне значення.
\end{abstract}

Nanopharmacology - a new direction of a science about medicines that studies the properties of nano medicines, especially their interaction with the organism [2]. Teaching of nanopharmacology for students of medical faculty at pre-graduate stage has a great scientific and methodological value.

Вступ. Вченими світу проводяться інтенсивні дослідження з вивчення властивостей природних і синтетичних матеріалів нанорозмірів. Тому доцільно у курсі лекцій і практичних занять уже на додипломному етапі викладати основні аспекти нанофармакології.

За останні роки в світі та в Україні значно збільшилася кількість досліджень 3 нанофармакології [2]. Уже застосовуються такі нанопрепарати: силікс, ліпін, мазь із наносрібла, капсули 3 нанозаліза, розчин із наномагнію. Для діагностики захворювань використовують нанозолото, фулерени, квантові мітки, дендримери. Слід відмітити, що ще недостатньо досліджень із вивчення токсикологічних властивостей наноматеріалів і нанопрепаратів.

Основна частина. Студенти медичних вузів повинні знати про основні досягнення наномедицини i

\section{Література}

1. Нанонаука і нанотехнології: технічний, медичний та соціальний аспекти / Б. Патон, В. Москаленко, І. Чекман, Б. Мовчан // Вісн. НАН України. - 2009. - № 6. - С. 18-26.

2. Чекман I. С. Нанофармакологія / І. С. Чекман. - К. : Задруга, 2011.-424 c.

3. Медицинская химия и клиническое применение диок- нанофармакології, що сприятиме підвищенню підготовки висококваліфікованих лікарів.

Вивчення основних властивостей нанопрепапаратів, особливостей їх взаємодії з організмом $€$ предметом досліджень учених світу. Досліджено фізико-хімічні властивості наночастинок $[1,3,4]$. Але недостатньо даних про їх біологічні, фармакологічні та токсикологічні властивості, молекулярні механізми взаємодії нанопрепаратів із клітинами організму.

На вступній лекції студентам повідомляють про основні досягнення світової фармакології. Залучають студентів до виконання досліджень 3 нанофармакології.

Висновок. Аналіз досліджень із нанофармакології показує, що вчені світу проводятьінтенсивні дослідження 3 нанонауки. Викладання студентам на додипломному етапі навчання основних положень із нанофармакології матиме важливе науково-педагогічне значення.

сида кремния / [А. А. Чуйко, В. К. Погорелый, А. А. Пентюк и др.]. - К. : Наукова думка. -2003. -415 с.

4. Jain K. K. Nanomedicine: application of nanobiotechnology in medical practice / K. K. Jain // Med. Princ. Pract.-2008. - Vol. 17, № 2. - P. 89-101. 